\title{
PERIPHERAL RURAL AREAS IN FACE OF CHALLENGES OF SUSTAINABLE DEVELOPMENT
}

\author{
Zofia Koloszko-Chomentowska ${ }^{1}$, Leszek Sieczko ${ }^{2}$ \\ ${ }^{1}$ Bialystok University of Technology, Poland; ${ }^{2}$ Warsaw University of Life Sciences, Poland \\ z.koloszko@pb.edu.pl, leszek_sieczko@sggw.pl
}

\begin{abstract}
Peripherality is always associated with a certain distance and involves differences in the level of socioeconomic development. Peripheral areas exist on different spatial scales. Persistent developmental disproportions solidify divisions in the country's spatial structure. Sustained differences in the economic potential of individual regions are one of the fundamental problems of the modern economy. The concept of sustainable development calls for equalization of the differences between developed and peripheral regions. The EU is striving to even out differences between regions in the Community through its cohesion policy. This paper gives an assessment of the development potential of peripheral regions using Poland as an example. The GDP value is about $30 \%$ lower than the mean value for the country, and depopulation processes are taking place in some communes. Investment outlays are also lower, however they indicate processes of production property reconstruction, and outlays for R\&D activity are also lower. Peripheral regions are distinguished by the richness of their natural environment. They have favorable conditions for the development of agriculture, including organic farming. No disruptions in ecological equilibrium are observed, however, no economic sustainability has been achieved.
\end{abstract}

Keywords: peripheral areas, sustainable development, rural areas.

\section{Introduction}

One of the most important tasks in regional development policy is the sustainable development of rural areas, mainly peripheral areas. The differences in the development level on the regional and subregional scale indicate such a need. Systemic and economic changes that occurred in Poland during the 90s caused a deepening of differences in the level of economic development, including in the level of agricultural development and development of rural areas. The causes of uneven development vary greatly, including, among other things, historically dictated neglect of economic development, demographic structure, settlement network, location relative to main centers. Poorly developed regions are defined as problem regions by the European Commission [1]. Such areas are also termed peripheral in the subject literature [2-6]. They are characterized by a low level of economic potential in comparison to areas with better economic development. The persistent nature of developmental disproportions leads to freezing of divisions in a country's spatial structure. Peripherality has many dimensions. It is most commonly perceived in the spatial sense, thus it pertains to areas with an unfavorable geographic position, distant from economically strong areas. Weak relations with the outside environment result in economic peripherality. Low economic activity and a meager labor market and low level of innovation resulting from this are the primary barriers to the economic development of peripheral regions.

In the EU's new Common Agricultural Policy for the years 2014-2020, it is emphasized that sustainable development of agriculture and the cultural heritage of rural areas are important factors in the stability of rural areas. Rural areas die out without small farms, without the activity of rural residents, without small service businesses. Peripheral rural areas are at particular risk of economic exclusion. Therefore, there is a need to integrate measures involving the search for solutions intended to preserve the assets of the natural environment, while simultaneously enabling the achievement of economic goals. These conditions are met by socially sustainable agriculture $[7 ; 8]$. One of the premises of this concept is the acknowledgment that not only market goods, but also public goods are important to the development of agriculture, and the acknowledgment that rationality and effectiveness in private and microeconomic activity should be linked to social rationality and effectiveness. As agriculture develops, it loses its original nature to an increasing extent, although natural or semi-open agriculture are viable structures that easily adapt to changing conditions. The features of natural farming are currently becoming attractive, as such farming provides values that other forms of farming lack, and the concept of sustainable development has become an example of global thinking about socioeconomic development. 
The concept of sustainable development calls for the equalization of differences between developed regions and peripheral regions. The EU strives to even out differences between regions of the Community through its cohesion policy. The experience of the Italian peripheral regions indicates that public funds have contributed to the suppression of depopulation processes in regions previously characterized by depopulation [9].

The goal of this paper is to assess the potential of peripheral areas and possibilities of their development in the context of the sustainable development concept. Assessment was conducted on the example of peripheral areas in Poland. In Poland, 5 voivodeships are classified as peripheral areas, making up $32 \%$ of the country's area.

\section{Materials and methods}

Objectives concerning environmental, economic and social areas of sustainability are accounted for in the concept of sustainable development. The integration of these objectives is a fundamental premise of the country's economic growth. Various indicators are applied to assess the level of sustainable development. The selection of indicators should consider the comparsion of indicators based on various criteria, mainly data availability [10].

The research problem was formulated based on mass statistics from the Central Statistical Office of Poland [11]. These data provide information about the resources of regions, including peripheral regions. Due to the availability of data, economic, environmental and social criteria were applied in assessment of the level of socioeconomic development.

Economic criteria consisted of the following indicators: GDP per capita, gross value of fixed assets, investment outlays in PLN per resident, outlays for research and development activity.

According to the concept of sustainable development, environmental protection is based on preservation and sustainable use of the environment's components. The following were adopted as criteria characterizing the natural environment: area of special nature value, protected forest area and outlays on fixed assets in environmental protection.

Agriculture exhibits special relationships with the natural environment, since it utilizes natural resources to an increasingly greater extent (than other sectors of industry). Hence, analysis accounts for features of agriculture indicating spatial management consistent with the concept of sustainable development. Meanwhile, the socio-demographic aspect of rural areas is presented on the basis of the following indicators: demographic load index, at-risk of poverty rate.

Analysis was conducted with respect to the year 2015.

\section{Results and discussion}

Gross domestic product per capita (GDP $p . c$.) is a commonly used measure for assessment of economic development. This indicator is approx. $30 \%$ lower than the national average in all peripheral regions (Tab.1). Changes of this indicator were small, which indicates that disproportions in socioeconomic development have persisted for years [12]. The level of GDP p. $c$. is below $40 \%$ of the average from EU-27. Over the past several years, the scale of differences in GDP $p$. $c$. increased at the regional and subregional level [11]. These data confirm the results of studies conducted by other authors, indicating growth of the scale of differences in the level of socioeconomic development at the regional and subregional levels.

Investment outlays are related to the process of property reconstruction and are also incurred for new production factors or improving the existing production factors. Thus, the value of investment outlays indicates modernization of technology. In peripheral regions, production factor reconstruction processes are present, however, outlays are significantly lower than the national average (from $18.6 \%$ in the Podlaskie voivodeship to $34.5 \%$ in the Świętokrzyskie voivodeship). Growth of the value of fixed assets is a consequence of investment outlays. In peripheral regions, the gross value of fixed assets is lower. The difference in the value of this indicator between individual regions and the national average is lower than in the case of investment outlays, since it ranges from $15.2 \%$ in the Podlaskie region up to $21.6 \%$ in the Lubelskie region. This shows that the majority of investments are related to the purchase of fixed assets. From the perspective of economic entities' growth, this is a favorable phenomenon, since fixed assets determine the production potential and competitiveness. 
However, interpretation of this indicator requires a certain degree of caution. It pertains to the gross value, so it does not account for the value of wear (depreciation). It may occur that the value of new investments does not cover the loss in the value of fixed assets resulting from their use.

Table 1

Economic indicators (2015)

\begin{tabular}{|c|c|c|c|c|}
\hline Region & $\begin{array}{c}\text { GDP* per } \\
\text { capita }\end{array}$ & $\begin{array}{c}\text { Investment } \\
\text { outlays, PLN } \\
\text { per capita }\end{array}$ & $\begin{array}{c}\text { Gross value of } \\
\text { fixed assets, } \\
\text { PLN per capita }\end{array}$ & $\begin{array}{c}\text { Research- } \\
\text { development activity } \\
\text { R\&D, PLN per capita }\end{array}$ \\
\hline Poland & 100.0 & 7069 & 90324 & 470 \\
\hline Lubelskie & 69.8 & 4837 & 70799 & 342 \\
\hline Podkarpackie & 70.8 & 5172 & 71854 & 427 \\
\hline Podlaskie & 72.4 & 5754 & 76621 & 253 \\
\hline Świętokrzyskie & 73.0 & 4624 & 70992 & 207 \\
\hline Warmińsko-Mazurskie & 71.5 & 5587 & 70950 & 107 \\
\hline
\end{tabular}

*2014. Source: Statistical Yearbook of the Regions, 2016

Another indicator providing information about economic development is the value of expenditures for R\&D activity. From this perspective, peripheral regions fall behind the rest of country. R\&D expenditures are $45 \%$ lower than the national average, with high variation between individual regions. Relatively, the enterprises located in the Podkarpackie region make the greatest R\&D expenditures. Compared to Poland as a whole, this is only $9 \%$ less. The largest industrial cluster in Poland is operating in this region, gathering entities from the aviation industry, which invest in modern technologies. In the other regions, $R \& D$ activity is at a much lower level.

Table 2

Characteristics of the natural environment

\begin{tabular}{|c|c|c|c|c|c|}
\hline \multirow[b]{2}{*}{ Specification } & \multicolumn{2}{|c|}{$\begin{array}{c}\text { Area of special nature } \\
\text { value }\end{array}$} & \multicolumn{2}{|c|}{ Protective forests area } & \multirow{2}{*}{$\begin{array}{c}\text { Outlays on } \\
\text { fixed assets in } \\
\text { environmental } \\
\text { protection, \% }\end{array}$} \\
\hline & ha & $\begin{array}{c}\% \text { of grand } \\
\text { total area }\end{array}$ & $\begin{array}{c}\text { thous. } \\
\text { ha }\end{array}$ & $\begin{array}{l}\text { \% of grand } \\
\text { total forest } \\
\text { areas }\end{array}$ & \\
\hline Poland & 10175972.9 & 32.5 & 3796.3 & 41.2 & 100.0 \\
\hline Lubelskie & 571524.6 & 22.7 & 127.3 & 21.8 & 2.8 \\
\hline Podkarpackie & 801228.2 & 44.9 & 406.0 & 59.7 & 3.3 \\
\hline Podlaskie & 642314.0 & 31.8 & 205.8 & 33.1 & 2.5 \\
\hline Świętokrzyskie & 761644.5 & 65.0 & 157.3 & 47.5 & 3.1 \\
\hline Warmińsko-Mazurskie & 1129519.3 & 46.7 & 269.6 & 35.8 & 1.8 \\
\hline
\end{tabular}

Source: Statistical Yearbook of the Regions, 2016

The data presented show that peripheral regions are more poorly developed from an economic perspective. Many factors affect this, among them, natural conditions for production and development. Peripheral areas are generally characterized by a production structure of low diversity, with a high share of traditional production. Activities related to farming and forestry production are dominant in peripheral regions. This is the result of the natural conditions and predispositions of these regions for agricultural and agriculture-related activity. Certain researchers of the development of rural areas distinguish areas of economic success in agricultural activity [13]. The Podlaskie voivodeship is one such area. In recent years, agriculture has undergone diversification and a group of commercial farms capable of competing on the domestic and European market has emerged.

Peripheral regions are characterized by a high share of areas of special nature value. In the Świętokrzyskie voivodeship, they make up $65 \%$ of the entire region's area. Areas of special nature value in the discussed regions make up $38.4 \%$ of Poland's area in total, and the mean value for the country is $32.5 \%$ (Tab.2). Forests subject to protection are also included among these areas. Those located in peripheral regions make up $30.7 \%$ of forest area in Poland. In total, this makes up over $60 \%$ of the area subject to various forms of protection, which entail restrictions on conduct of economic activity. 
Selected indicators of agriculture in peripheral regions

\begin{tabular}{|c|c|c|c|c|c|}
\hline \multirow[b]{2}{*}{ Specification } & \multirow[b]{2}{*}{$\begin{array}{c}\text { Permanent } \\
\text { grassland, } \\
\%\end{array}$} & \multirow[b]{2}{*}{$\begin{array}{l}\text { Cereals in } \\
\text { sowing, \% }\end{array}$} & \multirow[b]{2}{*}{$\begin{array}{c}\text { Mineral } \\
\text { fertilizers } \\
\text { NPK, kg·ha }{ }^{-1}\end{array}$} & \multicolumn{2}{|c|}{ Organic farms } \\
\hline & & & & Farms, \% & $\begin{array}{c}\text { Organic } \\
\text { agricultural } \\
\text { land, \% }\end{array}$ \\
\hline Poland & 21.5 & 55.2 & 117.3 & 100.0 & 100.0 \\
\hline Lubelskie & 15.9 & 62.2 & 126.6 & 8.1 & 5.9 \\
\hline Podkarpackie & 37.7 & 58.2 & 71.1 & 5.7 & 2.8 \\
\hline Podlaskie & 36.4 & 37.7 & 87.9 & 14.7 & 9.8 \\
\hline Świętokrzyskie & 21.1 & 59.7 & 121.8 & 3.8 & 2.0 \\
\hline Warmińsko-Mazurskie & 35.2 & 51.8 & 91.0 & 18.1 & 19.4 \\
\hline
\end{tabular}

Source: Statistical Yearbook of the Regions, 2016

Outlays on fixed assets in environmental protection are not large (1.8-3.3\%). This arises from the fact that the natural environment is not degraded and does not require high investment outlays.

Agriculture, which uses the natural environment, is the dominant sector of industry. Therefore, conducting agricultural production is linked to responsibility for management of the environment. One indicator of sustainable management in agriculture is the share of permanent grasslands.

They perform various ecological functions, and their greater share in the farmland structure means that there is less pressure on the environment. A particularly high share of permanent grasslands (over $35 \%$ ) is present in the regions: Podkarpackie, Podlaskie and Warmińsko-Mazurskie (Table 3).

Crop structure is the basic determinant of the organization of plant production. It is decisive to the production and economic effects, besides the level of fertilization and harvested crops. In the case of cereals, a share greater than $66 \%$ is to be avoided [14]. Data on crop structure in individual regions indicate that this condition was met. However, considering the high diversity of farms with respect to crop structure, it can be presumed that this condition was not met at the level of individual farms.

Consumption of mineral fertilizers (NPK) is at a very low level, and this is an advantage of agriculture in peripheral regions. Consumers benefit from this, because they receive products of high quality, but the environment also benefits since lesser consumption of mineral fertilizers means lower pressure on the environment. The natural conditions of peripheral regions combined with low consumption of chemical agents foster growth of organic farming. $50.4 \%$ of organic farms are located in peripheral regions, and they make up $39.9 \%$ of organic farmland in Poland (Tab.3).

Socio-demographic problems pose a certain limitation to the development of peripheral areas. The mean demographic load index in the voivodeships: Lubelskie, Podlaskie and Świętokrzyskie is higher than the national mean, but it is significantly higher in many communes, where depopulation processes also take place. Lower incomes are reflected in the phenomenon of poverty. Typically agricultural regions are at greater risk of poverty. Data from the Central Statistical Office [11] show that this phenomenon is more perceivable in peripheral regions than in other parts of the country (Tab.4).

Table 4

\section{Socio-demographic indicators}

\begin{tabular}{|c|c|c|c|}
\hline Specification & $\begin{array}{c}\text { Gross income per } \\
\text { capita (Poland = 100) }\end{array}$ & $\begin{array}{c}\text { Demographic } \\
\text { load index }\end{array}$ & $\begin{array}{c}\text { Risk of poverty } \\
\text { rate, \% }\end{array}$ \\
\hline Poland & 100.0 & 0.31 & 12.2 \\
\hline Lubelskie & 85.8 & 0.35 & 14.9 \\
\hline Podkarpackie & 78.5 & 0.29 & 17.1 \\
\hline Podlaskie & 82.6 & 0.32 & 13.4 \\
\hline Świętokrzyskie & 86.6 & 0.33 & 18.6 \\
\hline Warmińsko-Mazurskie & 104.6 & 0.29 & 21.1 \\
\hline
\end{tabular}

Source: Statistical Yearbook of the Regions, 2016 


\section{Conclusions}

Systemic and economic changes initiated at the beginning of the 1990s created opportunities for accelerating growth, but also deepened differences in the level of economic development between regions. This contradicts the concept of sustainable development. There are many causes of this state of affairs, however, it seems that under-appreciation of the role of agriculture and of rural areas as providers of public goods are among them. All of society uses these goods. The most important nonmarket functions of agriculture include: maintenance of socioeconomic activity in sparsely populated regions, protection of the natural environment within the scope of agriculture and rural areas, and preservation of rural cultural heritage. The realization of these functions is linked to the policy of rural areas' economic diversification.

The conducted analysis indicates that peripheral regions have rich environmental resources. The high share of traditional production in the economic structure does not limit the use of these regions' resources for development through promotion of alternative activity to industrial production. Above all, this includes production of healthy and safe food, which is of fundamental significance from the perspective of the national development strategy. Poland's peripheral voivodeships are an example of good use of natural conditions for development of agricultural production, including for promotion of organic farming. Almost $40 \%$ of the area of agricultural land is ecological land and in the peripheral regions consumption of mineral fertilizers is low (average $101.36 \mathrm{~kg} \cdot \mathrm{ha}^{-1}$ ). Therefore, it is justified to maintain the leading role of agriculture, and other functions should support the growth of this economic sector in the region. Meanwhile, the high share of areas subject to various forms of protection (average $42.2 \%$ of total area) creates conditions for the development of tourism and promotes a healthy lifestyle.

These areas deserve protection due to preservation of the biodiversity and sustainability of rural areas. Mean values of environmental sustainability indicators show that there are no significant threats to the environment, although such threats may occur at the level of individual farms. According to the concept of sustainable development, distribution of economic activity and growth should take place with respect to the principles of environmental protection. In analysis of the growth conditions in peripheral regions, it should be observed that while the ecological equilibrium is preserved, much is lacking in terms of economic sustainability. This is one of the most important challenges in modern development.

\section{Acknowledgements}

The research has been carried out in the framework of the work S/WZ/2/15 and funded by the Ministry of Science and Higher Education.

\section{References}

[1] A new partnership for for cohesion. Convergence, competitiveness, cooperation. Third report on economic and social cohesion. Luxembourg: European Commission, 2004. [online] [15.03.2018]. Available at:

http://ec.europa.eu/regional_policy/sources/docoffic/official/reports/pdf/cohesion3/cohesion3_toc _en.pdf

[2] Bajerski A. Problemy wydzielania peryferii społeczno-gospodarczych (Problems with delimitation of socio-economic peripheries). Ruch Prawniczy, Ekonomiczny i Socjologiczny, no LXX (2), pp. 159-167. (In Polish).

[3] Leszczewska K. Specyfika regionów peryferyjnych (w:) Uwarunkowania różnic ekonomicznych i społecznych ((The specificity of peripheral regions (in:) Conditions of economic and social differences), Łomża: Państwowa Wyższa Szkoła Informatyki i Przedsiębiorczości, 2011, pp. 107126. (In Polish).

[4] Olechnicka A. Regiony peryferyjne w gospodarce informacyjnej (Peripheral regions in the information economy). Warszawa: SCHOLAR, 2004. 206 p. (In Polish).

[5] Proniewski M. Polityka rozwoju regionów peryferyjnych (Development policy of peripheral regions). Optimum Studia Ekonomiczne, no 6(72), 2014, pp. 79-90. (In Polish). 
[6] Stanny M. Typologia wiejskich obszarów peryferyjnych pod względem anatomii struktury społeczno-gospodarczej (A typology of rural peripherial areas in Poland: anatomy of the socioeconomic structure). Wieś i Rolnictwo, no 2(151), 2011, pp. 59-75. (In Polish).

[7] Krasowicz S. W Polsce powinno dominować rolnictwo zrównoważone (Sustainable agriculture should dominante in Poland). I Kongres Nauk Rolniczych "Przyszłość sektora rolno-spożywczego i obszarów wiejskich" (1st Congress of Agricultural Sciences "The future of the agri-food sector and rural areas", Puławy: IUNG-PIB, 2009, pp. 21-38. (In Polish).

[8] Zegar J.S. Zrównoważenie polskiego rolnictwa. (Sustainability of Polish agriculture). Warszawa: GUS, 2013. (In Polish).

[9] Steinicke E., Cede P., Fliesser U. Development patterns of rural depopulation areas. Demographic impacts of amenity migration on Italian peripheral regions. Mitteilungen Der Osterreichischen Geographischen Gesellschaft, Vol. 151, pp. 195-214.

[10] Lebacq T., Baret P.V., Stihmant D. Sustainability indicators for livestock farming. A review. Agronomy for Sustainable Development, no 33(2), 2013, pp. 311-327.

[11] Statistical Yearbook of the Regions. Warszawa: Central Statistical Office, 2016 (In Polish).

[12] Koloszko-Chomentowska Z. The role of agriculture in the development of peripheral rural areas. Proceedings of International Scientific Conference on Economic and Social Development "Building resilient society", December 8-9, 2017, Zagreb, Croatia, pp. 699-703.

[13] Bański J. Wiejskie obszary sukcesu gospodarczego (Economically successful rural areas). Studia Obszarów Wiejskich PTG, IGiPZ PAN, no 14, pp. 1-146. (In Polish).

[14]Duer I., Fotyma M., Madej A. Kodeks Dobrej Praktyki Rolniczej (Code of Good Agricultural Practice). Warszawa: MRiRW-MS-FAPA, 2002.93 p. (In Polish). 